\title{
On the issue of defining safe distances and overpressure under impact of shock air blast wave (Magnesitovaya mine)
}

\author{
Sergey Zharikov ${ }^{1}$, Vyacheslav Kutuev ${ }^{1 *}$ \\ ${ }^{1}$ Institute of Mining of the Ural branch of the Russian Academy of Sciences, 620075, 58, Mamina- \\ Sibiryak, Ekaterinburg, Russia
}

\begin{abstract}
As the depth of mining increases, attention to the preservation of mine workings and mining blasting is steadily growing. Technological methods of effective mineral development are often limited by dynamic blasting impact causing short-period fluctuations in the rock mass. Therefore, correct explosion impact identification, to a great extent, determines effective mining trends. Some results of researches for minimum blasting impact on mining workings are given in the article. Calculation of safe distances and excess pressure at shock air impact of technological explosions on the Magnezitovaya mine personnel was made. The calculation was made for the $15.5 \mathrm{~m}$ mine working section, with two conditions of the total section of the mine workings adjacent to the face of $15.5 \mathrm{~m}$ and $31 \mathrm{~m}$ with distances of $50 \mathrm{~m}$ and $100 \mathrm{~m}$. Overpressure was also calculated for a total cross-section of $15.5 \mathrm{~m}$ and distances of 150 and 200 $\mathrm{m}$. It was determined that the safe distance for people under overpressure conditions at the shock air wave front, depending on breaking schemes, is in the range of 150-200 m. The urgency of this research is to ensure industrial safety of underground mining operations.

Keywords: blasting operations, technological explosion, blasting operations in underground mine workings, shock air wave, excessive pressure at the front of shock air wave (SAW)
\end{abstract}

\section{Introduction}

Urgency of the research of underground explosions impact is determined by the necessity to determine the safety of new and improve the existing systems for mineral development and their parameters, within the pilot industrial testing. The assessment of explosions consequences is necessary for subsequent selection of acceptable drilling and blasting options in specific areas, depending on the actual underground working space. Our task was to determine the safe distances and overpressure of technological explosions during cleaning operations in the Magnezitovaya mine under industrial conditions.

\footnotetext{
*Corresponding author: slavik1988@mail.ru
} 


\section{Industrial explosive}

Industrial granular grammonite $\mathrm{TM}$ explosive is used for blasting operations at the Magnezitovaya mine. Its purpose is manual and mechanized charging of dry and drained boreholes, wells and chambers on the earth's surface and in the faces of underground mines, non-hazardous for gas and dust in the temperature range from -50 to $+50{ }^{\circ} \mathrm{C}$ for medium hard and hard rocks, except for sulfide ores.

An intermediate detonator is necessary for grammonite TM initiation. For open working one intermediate charge T-400G or $2 \ldots 3$ cartridges of ammonite 6ZhV (GOST - Russian National Standard 21984-76) with a cartridge weight of $200 \ldots 250 \mathrm{~g}$ are enough, and a cartridge-packed ammonite $6 \mathrm{ZhV}$ with weight not less than $200 \mathrm{~g}$ is used for underground operations.

Grammonite TM is the explosive, fire hazardous and toxic substance. It is sensitive to mechanical and thermal effects. It should be protected from strong mechanical action, any external fire and heating sources, soaking, atmospheric precipitation and direct sun rays.

The main physical-chemical and explosive characteristics of grammonite TM are presented in Table 1.

Table 1. Physical-chemical and explosive characteristics of grammonite TM [1]

\begin{tabular}{|c|c|}
\hline Characteristics & Standard \\
\hline Appearance & $\begin{array}{l}\text { Mixture of ammonium nitrate } \\
\text { granules and crystals with } \\
\text { granulatole and petroleum product }\end{array}$ \\
\hline Mass fraction of moisture and volatile substances, $\%$ & 0.7 \\
\hline Explosive heat, $\mathrm{kJ} / \mathrm{kg}$ & $3938(940)$ \\
\hline $\begin{array}{l}\text { Volume of gases, } 1 / \mathrm{kg} \text {, toxic fumes including calculated on } \mathrm{CO}, 1 / \mathrm{kg} \text {, } \\
\text { not more than }\end{array}$ & $\begin{array}{c}854 \\
24 \\
\end{array}$ \\
\hline Oxygen balance, $\%$ & -0.36 \\
\hline Trinitrotolul equivalent by explosion heat & 0.94 \\
\hline Charging density, $\mathrm{g} / \mathrm{cm}^{3}$ & $1.0 \ldots 1.15$ \\
\hline Detonation velocity, $\mathrm{m} / \mathrm{s}$ & $2200 \ldots 3500$ \\
\hline Critical detonation diameter in steel pipe, $\mathrm{mm}$ & 19 \\
\hline Brisance (GOST 5984-99), mm & 23 \\
\hline $\begin{array}{l}\text { Impact sensitivity (GOST } 4545-88 \text { ): } \\
\text { Blast frequency in the device } 1, \% \\
\text { lower limit in the device } 2, \mathrm{~mm}\end{array}$ & $\begin{array}{l}24 \ldots 40 \\
200\end{array}$ \\
\hline Friction sensitivity to (GOST R50835-95), lower limit, $\mathrm{mPa}$ & 490 \\
\hline Flash point, ${ }^{\circ} \mathrm{C}$ & $346 \ldots 349$ \\
\hline Volume resistivity, Ohm*m & $2.9 * 10^{6}$ \\
\hline
\end{tabular}

\section{Theory and Calculation Results}

The overpressure is determined at the shock air waves (SAW) front to specify the safe distances of the SAW impact to exclude the people injury, facilities and technological equipment damage during underground mine blasting [2-12] (expression (1)). The calculation was made for the mine section of $15.5 \mathrm{~m}$, two variants of the total section of the mine workings adjacent to the face of $15.5 \mathrm{~m}$ and $31 \mathrm{~m}$ with the calculated distances of 50 $\mathrm{m}$ and $100 \mathrm{~m}$. Overpressure was also calculated for a total cross-section of $15.5 \mathrm{~m}$ and distances of $150 \mathrm{~m}$ and $200 \mathrm{~m}$.

$$
\Delta P=\left(3410 \frac{Q_{e}}{R \sum S}+794 \sqrt{\frac{Q_{e}}{R \sum S}}\right) \cdot e^{-\frac{\beta R}{d}}, \mathrm{kPa},
$$

where $\sum \mathrm{S}$ - the total cross-section area of the mine workings adjacent to the charge (two variants are taken into account $15.5 \mathrm{~m}$ and $31 \mathrm{~m}$ ); $R$ - distance; $e$ - base of the natural 
logarithm $=2.71 ; d$ - equivalent diameter of mine working; $\beta$ - surface roughness coefficient (accepted 0.07) $\sum \mathrm{S}=31 \mathrm{~m}$.

$$
d=1.12 \sqrt{S}, \mathrm{~m},
$$

Equivalent charge $\left(Q_{e}\right)$ is defined as follows:

$$
Q_{e}=12 P d K_{s} N, \mathrm{~kg},
$$

where $d$ - diameter of the blast chamber; $K_{s}$ - coefficient taking into account the ratio of the length of stemming or the undercharged part of the blast chamber to the borehole diameter; $\mathrm{N}$ - number of charges in the group.

Calculation was made according to FRaR (Federal Rules and Regulations): Safety Regulations for Blasting Operation [13]. Results of calculations are presented in tables 2 6.

Table 2. Equivalent weight of explosives depending on blasting conditions

\begin{tabular}{|c|c|c|c|c|c|c|c|c|}
\hline Borehole & Charging & \multicolumn{7}{|c|}{ Equivalent weight $Q_{\mathrm{e}}, \mathrm{kg}$} \\
\cline { 3 - 10 } $\begin{array}{c}\text { diameter, } \\
\mathrm{m}\end{array}$ & $\begin{array}{c}\text { density, } \\
\mathrm{kg} / \mathrm{m}^{3}\end{array}$ & 6 charges & 9 charges & 11 charges & 12 charges & 13 charges & 15 charges & 16 charges \\
\cline { 3 - 10 } & 1000 & 0.6 & 1.4 & 1.6 & 1.8 & 2.2 & 2.5 & 3.4 \\
\hline \multirow{3}{*}{0.089} & 1100 & 0.7 & 1.6 & 1.8 & 2.0 & 2.4 & 2.7 & 3.7 \\
\cline { 2 - 10 } & 1150 & 0.7 & 1.6 & 1.8 & 2.1 & 2.5 & 2.9 & 3.9 \\
\hline \multirow{3}{*}{0.076} & 1000 & 0.2 & 0.6 & 0.6 & 0.6 & 0.6 & 0.7 & 1.0 \\
\cline { 2 - 10 } & 1100 & 0.3 & 0.6 & 0.7 & 0.7 & 0.7 & 0.8 & 1.1 \\
\cline { 2 - 10 } & 1150 & 0.3 & 0.6 & 0.7 & 0.7 & 0.7 & 0.9 & 1.1 \\
\hline
\end{tabular}

\begin{tabular}{|c|c|c|c|c|c|c|c|c|c|}
\hline \multirow[t]{3}{*}{$\sum \mathrm{S}, \mathrm{m}$} & \multirow{3}{*}{$\begin{array}{l}\text { Borehole } \\
\text { diameter, } \\
\mathrm{m}\end{array}$} & \multirow{3}{*}{$\begin{array}{c}\text { Charging } \\
\text { density, } \\
\mathrm{kg} / \mathrm{m}^{3}\end{array}$} & \multicolumn{7}{|c|}{ Overpressure at $50 \mathrm{~m}$ distance, $\mathrm{kPa}$} \\
\hline & & & \multicolumn{7}{|c|}{ Number of charges in group } \\
\hline & & & $\begin{array}{c}6 \\
\text { charges }\end{array}$ & $\begin{array}{c}9 \\
\text { charges }\end{array}$ & $\begin{array}{c}11 \\
\text { charges }\end{array}$ & $\begin{array}{c}12 \\
\text { charges }\end{array}$ & $\begin{array}{c}13 \\
\text { charges }\end{array}$ & $\begin{array}{c}15 \\
\text { charges }\end{array}$ & $\begin{array}{c}16 \\
\text { charges }\end{array}$ \\
\hline \multirow{6}{*}{15.5} & \multirow{3}{*}{0.089} & 1000 & 17.4 & 27.5 & 29.4 & 31.7 & 34.9 & 38.0 & 45.9 \\
\hline & & 1100 & 18.3 & 29.1 & 31.1 & 33.6 & 37.0 & 40.3 & 48.7 \\
\hline & & 1150 & 18.8 & 29.8 & 31.9 & 34.5 & 38.0 & 41.4 & 50.0 \\
\hline & \multirow{3}{*}{0.076} & 1000 & 10.4 & 16.2 & 17.4 & 17.5 & 17.5 & 19.0 & 22.3 \\
\hline & & 1100 & 10.9 & 17.0 & 18.3 & 18.5 & 18.5 & 20.0 & 23.5 \\
\hline & & 1150 & 11.2 & 17.5 & 18.8 & 18.9 & 18.9 & 20.5 & 24.1 \\
\hline \multirow{6}{*}{31} & \multirow{3}{*}{0.089} & 1000 & 15.0 & 23.4 & 24.9 & 26.9 & 29.5 & 32.0 & 38.3 \\
\hline & & 1100 & 15.8 & 24.7 & 26.3 & 28.3 & 31.1 & 33.8 & 40.5 \\
\hline & & 1150 & 16.2 & 25.3 & 27.0 & 29.1 & 31.9 & 34.7 & 41.6 \\
\hline & \multirow{3}{*}{0.076} & 1000 & 9.1 & 14.0 & 15.0 & 15.1 & 15.1 & 16.3 & 19.1 \\
\hline & & 1100 & 9.5 & 14.7 & 15.8 & 15.9 & 15.9 & 17.2 & 20.1 \\
\hline & & 1150 & 9.8 & 15.1 & 16.2 & 16.3 & 16.3 & 17.6 & 20.6 \\
\hline
\end{tabular}

Table 3. Overpressure according to conditions at a distance of $50 \mathrm{~m}$ 
Table 4. Overpressure according to conditions at a distance of $100 \mathrm{~m}$

\begin{tabular}{|c|c|c|c|c|c|c|c|c|c|}
\hline \multirow[t]{3}{*}{$\sum \mathrm{S}, \mathrm{m}$} & \multirow{3}{*}{$\begin{array}{c}\text { Borehole } \\
\text { diameter, } \\
\mathrm{m}\end{array}$} & \multirow{3}{*}{$\begin{array}{c}\text { Charging } \\
\text { density, } \\
\mathrm{kg} / \mathrm{m}^{3}\end{array}$} & \multicolumn{7}{|c|}{ Overpressure at100 $\mathrm{m}$ distance, $\mathrm{kPa}$} \\
\hline & & & \multicolumn{7}{|c|}{ Number of charges in group } \\
\hline & & & $\begin{array}{c}6 \\
\text { charges }\end{array}$ & $\begin{array}{c}9 \\
\text { charges }\end{array}$ & $\begin{array}{c}11 \\
\text { charges }\end{array}$ & $\begin{array}{c}12 \\
\text { charges }\end{array}$ & $\begin{array}{c}13 \\
\text { charges }\end{array}$ & $\begin{array}{c}15 \\
\text { charges }\end{array}$ & $\begin{array}{c}16 \\
\text { charges }\end{array}$ \\
\hline \multirow{6}{*}{15.5} & \multirow{3}{*}{0.089} & 1000 & 5.4 & 8.4 & 9.0 & 9.7 & 10.6 & 11.5 & 13.8 \\
\hline & & 1100 & 5.7 & 8.9 & 9.5 & 10.2 & 11.2 & 12.1 & 14.6 \\
\hline & & 1150 & 5.8 & 9.1 & 9.7 & 10.5 & 11.5 & 12.5 & 14.9 \\
\hline & \multirow{3}{*}{0.076} & 1000 & 3.3 & 5.0 & 5.4 & 5.4 & 5.4 & 5.9 & 6.9 \\
\hline & & 1100 & 3.4 & 5.3 & 5.7 & 5.7 & 5.7 & 6.2 & 7.2 \\
\hline & & 1150 & 3.5 & 5.4 & 5.8 & 5.9 & 5.9 & 6.3 & 7.4 \\
\hline \multirow{6}{*}{31} & \multirow{3}{*}{0.089} & 1000 & 5.2 & 8.0 & 8.6 & 9.2 & 10.1 & 10.9 & 12.9 \\
\hline & & 1100 & 5.5 & 8.5 & 9.0 & 9.7 & 10.6 & 11.5 & 13.7 \\
\hline & & 1150 & 5.6 & 8.7 & 9.2 & 9.9 & 10.9 & 11.8 & 14.0 \\
\hline & \multirow{3}{*}{0.076} & 1000 & 3.2 & 4.9 & 5.2 & 5.2 & 5.2 & 5.7 & 6.6 \\
\hline & & 1100 & 3.3 & 5.1 & 5.5 & 5.5 & 5.5 & 6.0 & 6.9 \\
\hline & & 1150 & 3.4 & 5.2 & 5.6 & 5.6 & 5.6 & 6.1 & 7.1 \\
\hline
\end{tabular}

Table 5. Overpressure according to conditions at a distance of $150 \mathrm{~m}$

\begin{tabular}{|c|c|c|c|c|c|c|c|c|c|}
\hline \multirow{3}{*}{$\sum \mathrm{S}, \mathrm{m}$} & \multirow{3}{*}{$\begin{array}{c}\text { Borehole } \\
\text { diameter, } \\
\mathrm{m}\end{array}$} & \multirow{3}{*}{$\begin{array}{l}\text { Charging } \\
\text { density, } \\
\mathrm{kg} / \mathrm{m}^{3}\end{array}$} & \multicolumn{7}{|c|}{ Overpressure at $150 \mathrm{~m}$ distance, $\mathrm{kPa}$} \\
\hline & & & \multicolumn{7}{|c|}{ Number of charges in group } \\
\hline & & & $\begin{array}{c}6 \\
\text { charges }\end{array}$ & $\begin{array}{c}9 \\
\text { charges }\end{array}$ & $\begin{array}{c}11 \\
\text { charges }\end{array}$ & $\begin{array}{c}12 \\
\text { charges }\end{array}$ & $\begin{array}{c}13 \\
\text { charges }\end{array}$ & $\begin{array}{c}15 \\
\text { charges }\end{array}$ & $\begin{array}{c}16 \\
\text { charges }\end{array}$ \\
\hline \multirow{6}{*}{15.5} & \multirow{3}{*}{0.089} & 1000 & 2.0 & 3.0 & 3.2 & 3.5 & 3.8 & 4.1 & 4.9 \\
\hline & & 1100 & 2.1 & 3.2 & 3.4 & 3.7 & 4.0 & 4.4 & 5.2 \\
\hline & & 1150 & 2.1 & 3.3 & 3.5 & 3.8 & 4.1 & 4.5 & 5.3 \\
\hline & \multirow{3}{*}{0.076} & 1000 & 1.2 & 1.8 & 2.0 & 2.0 & 2.0 & 2.1 & 2.5 \\
\hline & & 1100 & 1.3 & 1.9 & 2.1 & 2.1 & 2.1 & 2.2 & 2.6 \\
\hline & & 1150 & 1.3 & 2.0 & 2.1 & 2.1 & 2.1 & 2.3 & 2.7 \\
\hline
\end{tabular}

Table 6. Overpressure according to conditions at a distance of $200 \mathrm{~m}$

\begin{tabular}{|c|c|c|c|c|c|c|c|c|c|}
\hline \multirow[t]{3}{*}{$\sum \mathrm{S}, \mathrm{m}$} & \multirow{3}{*}{$\begin{array}{c}\text { Borehole } \\
\text { diameter, } \\
\mathrm{m}\end{array}$} & \multirow{3}{*}{$\begin{array}{l}\text { Charging } \\
\text { density, } \\
\mathrm{kg} / \mathrm{m}^{3}\end{array}$} & \multicolumn{7}{|c|}{ Overpressure at $200 \mathrm{~m}$ distance, $\mathrm{kPa}$} \\
\hline & & & \multicolumn{7}{|c|}{ Number of charges in group } \\
\hline & & & $\begin{array}{c}6 \\
\text { charges } \\
\end{array}$ & $\begin{array}{c}9 \\
\text { charges } \\
\end{array}$ & $\begin{array}{c}11 \\
\text { charges }\end{array}$ & $\begin{array}{c}12 \\
\text { charges } \\
\end{array}$ & $\begin{array}{c}13 \\
\text { charges }\end{array}$ & $\begin{array}{c}15 \\
\text { charges } \\
\end{array}$ & $\begin{array}{c}16 \\
\text { charges } \\
\end{array}$ \\
\hline \multirow{6}{*}{15.5} & \multirow{3}{*}{0.089} & 1000 & 0.8 & 1.2 & 1.3 & 1.3 & 1.5 & 1.6 & 1.9 \\
\hline & & 1100 & 0.8 & 1.2 & 1.3 & 1.4 & 1.6 & 1.7 & 2.0 \\
\hline & & 1150 & 0.8 & 1.3 & 1.4 & 1.5 & 1.6 & 1.7 & 2.1 \\
\hline & \multirow{3}{*}{0.076} & 1000 & 0.5 & 0.7 & 0.8 & 0.8 & 0.8 & 0.8 & 1.0 \\
\hline & & 1100 & 0.5 & 0.8 & 0.8 & 0.8 & 0.8 & 0.9 & 1.0 \\
\hline & & 1150 & 0.5 & 0.8 & 0.8 & 0.8 & 0.8 & 0.9 & 1.0 \\
\hline
\end{tabular}

The data in Tables $3-6$, according to the selected conditions, indicate the following: 
- up to $50 \mathrm{~m}$ from the explosion, the overpressure exceeds the maximum permissible pressure for a person $(10 \mathrm{kPa})$ [13] almost in all cases and it is dangerous to be at this distance (dark grey);

- at a distance of $100 \mathrm{~m}$ from the explosion, the pressure is less, but in some conditions its value is also dangerous and exceeds $10 \mathrm{kPa}$;

- at a distance of $150 \mathrm{~m}$ all values are less than the maximum permissible, but the lower limit of damage for a person is present $(5 \mathrm{kPa})[14]$;

- at a distance of $200 \mathrm{~m}$ the calculated pressure values are less than $2.2 \mathrm{kPa}$.

Therefore, according to the calculated data in Table 6, at a distance of $200 \mathrm{~m}$, injury of a person is unlikely.

\section{Conclusions}

Thus, in the course of drilling and blasting operations with the accepted parameters specified above, the safe distance for overpressure at the SAW front for people, depending on the breakout scheme, is in the range of $150-200 \mathrm{~m}$. This distance refers to the personnel forced to be close to the place of blasting operations. In other cases, the safety distance for people should be increased according to the FNiP "Safety regulations for blasting operations" [13].

\section{Acknowledgements}

The research has been carried out within the framework of State Proposal, theme \# 04052019-0005 (2019 - 2021), and with additional attraction of contract-based funding

\section{References}

1. TU 84-08628424-740-2002 Industrial explosives. Grammonite TM (2002)

2. M.A. Sadovsky, Selected works: Geophysics and physics of explosion (Science, Moscow, 2004)

3. Physics of Explosion, (FIZMATLIT, Moscow), (2002)

4. Y. I. Tseytlin, N. I. Smoliy, Seismic and shock air waves of industrial explosions, 192. Moscow, Nedra Publ., (1981)

5. P.V. Menshikov, Subsurface and Mineral Management, 2 (25), 145 (2020)

6. P.V. Menshikov, S.S. Taranzhin, A.S. Flyagin, E3S Web of Conferences 177, 03021 (2020)

7. M.V. Kornilkov, V.G. Shemenev, P. V. Menshikov, V.A. Sinitsyn, News of the Higher Institutions. Mining Journal 7, 65 (2013)

8. P. V. Menshikov, Technology and safety of blasting, 211 (2011)

9. P. V. Menshikov, Mining Informational and Analytical Bulletin, 11, 321 (2010)

10. P. V. Menshikov Explosion Technology, 97(54), 77 (2007)

11. S. Simoni, R. Sidler, J. Dual, J. Schweizer, Science and Technology J. 120, 179 (2015)

12. K. Kim, A. Rodgers, Geophys. Res. Lett. 43, 6883 (2016)

13. Federal regulations and rules in industrial safety. Blasting safety regulations (TH "UralYurIzdat", Ekaterinburg, 2018)

14. GOST $R$ 12.3.047-98 Occupational safety standards system. Fire safety of technological processes. General requirements. Control methods (1998) 